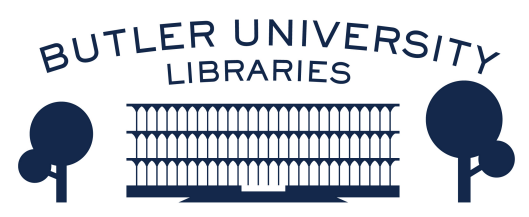

Journal of Hindu-Christian Studies

Volume 27

Article 10

November 2014

\title{
Viewpoint: Convenience, Consumption and Creatureliness: Thoughts on Sacred Groves, Hindu and Christian
}

Eliza F. Kent
Skidmore College

Follow this and additional works at: https://digitalcommons.butler.edu/jhcs

Part of the History of Religions of Eastern Origins Commons

\section{Recommended Citation}

Kent, Eliza F. (2014) "Viewpoint: Convenience, Consumption and Creatureliness: Thoughts on Sacred Groves, Hindu and Christian," Journal of Hindu-Christian Studies: Vol. 27, Article 10.

Available at: https://doi.org/10.7825/2164-6279.1582

The Journal of Hindu-Christian Studies is a publication of the Society for Hindu-Christian Studies. The digital version is made available by Digital Commons @ Butler University. For questions about the Journal or the Society, please contact cbauman@butler.edu. For more information about Digital Commons @ Butler University, please contact digitalscholarship@butler.edu. 


\title{
Viewpoint: \\ Convenience, Consumption and Creatureliness: Thoughts on Sacred Groves, Hindu and Christian
}

\author{
Eliza F. Kent \\ Skidmore College
}

WHEN I was doing field research in India regularly from 2001-2007, I kept hearing an expression for "rich person" I'd never heard before - "vasati-karar," where "vasati" can be loosely rendered as "convenience." As the liberalization of India's economy gained traction in the 2000s, lots of people were acquiring vasatis. Increasingly affordable and accessible consumer items like electric fans and mixie-grinders, cars and laptop computers were making life easier and more comfortable for people across the social spectrum. Temples and churches did not miss out on the boom. Ceiling fans and electric light eased the strain of sitting through long services, while the electrified loud speakers mounted on every house of worship spoke or sang to the faithful (and everyone else) at higher volumes and across wider expanses of space than ever before. Moreover, with each status-laden acquisition, individuals and groups got a little boost of self-esteem and created emotional ripples among their neighbors: envy, pride, desire, competition, satisfaction, and so on.

I spent a lot of time thinking about convenience and consumption that year as I observed that one of the biggest threats to the forested village shrines I was researching was the drive to "clean up," develop or civilize (nagarikka) both the deity and the community of devotees bound together around Him or Her. These forested shrines are Tamil Nadu's instantiation of the phenomenon of "sacred groves" found throughout India and around the world, where small forests or stands of trees protected from human overuse by religious taboos. In Tamil Nadu, sacred groves are typically associated with fierce village gods and goddesses like Sri Aiyannar and Sri Karuppusami. As warriors and hunters who protect the village from ghosts, disease and other threats, the forest is seen as a suitable

Eliza F. Kent is Professor of Religion at Skidmore College. A scholar of religion in South Asia, she earned her Ph.D. from the University of Chicago Divinity School and specializes in the manifold side effects of religious encounter, including conversion, syncretism, revival and reform. She is the author of Converting Women: Gender and Protestant Christianity in Colonial South India (Oxford University Press, 2004), which won the award for Best Book in Hindu-Christian Studies, 2003-2005, and Sacred Groves, Local Gods: Religion and Environmentalism in South India_(Oxford University Press, 2013). With Tazim Kassam, she is co-editor of Lines in Water: Religious Boundaries in South Asia (Syracuse University Press, 2013). 
home for such deities; moreover, their potentially dangerous quixotic nature motivates village residents to keep them a bit at a distance. Besides playing important roles in village Hinduism, the sacred groves they preside over also provide precious habitat for endangered and endemic taxa in landscapes otherwise denuded of forest. My heart broke a little every time I saw, or heard about, a forested shrine cleared to make room for a "pukka" concrete temple. But how could I argue with the drive towards comfort and convenience, not to mention status that motivated the "improvement " of a shrine, even if it meant clearing a bit of natural forest cover? If I was more comfortable sitting under a roof sheltered from rain and sun, why wouldn't Sri Karuppusami and His devotees be too?

In January, I had a chance to compare the Hindu sacred groves of Tamil Nadu with a very similar phenomenon in the Amharic-speaking highlands of Ethiopia, where one almost invariably finds small forests surrounding the rural churches of the Ethiopian Tewahido Orthodox Church. Here too, church forests constitute islands of biodiversity in an ocean of degraded land, where their use is strictly regulated by religious taboos. Each ETOC church, and its surrounding forest, is associated with the Virgin Mary, Saint Michael, Saint Gabriel or another crucial intermediary between the faithful and God. Beliefs about purity, pollution and access to the divine strikingly similar to those of Brahmanical Hinduism organize the space around the physical churches in a series of concentric circles, at the center of which resides the tabot, a replica of the tablets of the divine law brought down from Mount Sinai by Moses.
The forest of such a church constitutes the outermost circle and serves, among other things, as a community burial ground, where towering trees serve as a beautiful symbol of continuity across the generations.

Here, as in India, economic forces global in scale have transformed people's lives, inculcating new dreams and aspirations. Over the last five years, wealthy individuals have begun to construct semi-permanent grave houses in ETOC church forests. Traditionally, the deceased would be buried under piles of rocks in shallow graves that disappeared into the forest after six to seven years. Nowadays, grave houses built of stone and eucalyptus beams create a convenient shelter from rain and sun for relatives marking death anniversaries or gathering at the church for other occasions. Wherever they are built, one or two ancient trees are inevitably felled and that space is no longer available for forest regeneration. Nor do members of the community gather in the same way as they used to, now that wealthy families have a dryer or cooler place to sit, apart from the hoi polloi. As in India, every convenience acquired, every "development" built creates ripples in all directions.

I recognize that as a privileged white woman in the US I have no morally defensible place from which to object when hard-working people in Ethiopia or India use their resources to secure some comfort and status. The need to restrain the desire to consume grows every more urgent for all of us, especially those of us who reside in the global North, where conspicuous consumption is practically a blood-sport and "affluenza" a common ailment. And yet, as scholars, citizens, people of faith and thoughtful people whether in India, North 
America or elsewhere, I submit we do have an obligation to care about the effects of the spread of consumer culture around the world, and to cautiously - contribute to interventions to mitigate its worst effects, which we in the global North have come to know all too well. For we have the dubious fortune of living in a historical moment prophesied by Mohandas Gandhi. In his masterpiece, Hind Swaraj (1909), written at a feverish pace over the course of a ten-day sea voyage, Gandhi sharply critiqued that variety of civilization that made "bodily welfare the object of life." "This civilization," he wrote, "is irreligion [adharma], and it has taken such a hold on the people in Europe that those who are in it appear to be half mad." Elsewhere he wrote that if the people of India (and we might now add, all developing countries North and South, East and West) were to catch the "disease" of industrialized civilization, and embark on economic exploitation the way the British did, the whole world would be consumed as if by a swarm of locusts (Young India [1928], p. 422).

In this context, sacred groves, already burdened with associations, take on yet one more meaning as symbols of the perennial tension between desire and restraint so central to Christian and Hindu thought and practice. Though here what is at stake is not so much the state of our souls, but the future of the world's biodiversity. It is amazing that these forests have survived for as long as they have given the massive transformations India and Ethiopia have undergone since the 1940s: political upheaval, land reform, not to mention rising population pressure and the accompanying demand for fuelwood, timber, fodder and agricultural land. The question of what has permitted these patches of native forest to endure when the land all around them has been put to more "productive" purposes is a central concern of research on sacred groves. Perhaps answering that question has value not only for those working to conserve Indian or Ethiopian sacred groves, but for all of us confronting the reality of our ecological crisis.

One puzzle is that there is very little explicit ecological ethos to be found in the beliefs and practices surrounding these forested sacred sites, whether Hindu or Orthodox Christian. One can certainly find ample encouragement to steward the earth in both traditions, as so many brilliant scholars in the field of religion and ecology have shown. But in speaking with ordinary priests, devotees, and church members it is striking how seldom they mention anything about the trees or the forest, let alone articulate ideas about the religious or spiritual value of the forest per se. My field research suggests that the main belief restraining use of the forest in both cases is simply that the forest belongs to the village deity, or to the saint. It is His, or more rarely, Hers. Thus, it may be that nothing more than a kind of pragmatic humility keeps ordinary people from gathering fuel wood in the sacred forest, or cutting a sapling to make a plough part, or a mature tree for a house beam. You don't steal from your local saint or from the village guardian deity (sami). Some scholars have emphasized the deterrent effect of supernatural sanctions in preserving these sites; indeed, both saints and samis are eminently capable of inflicting harm on those who transgress the taboos surrounding these sites. But I suspect that beneath or alongside the fear of retribution is something else, perhaps that spiritual sixth sense that Friedrich Schleiermacher and Rudolf Otto described so 
movingly: that sense of one's smallness in the face of the divine, of one's utter dependence on the divine. How can such a slender thing restrain the drive for one's own comfort and ease, and for the admiration of one's neighbors, when the pleasant payoff is immediate and the costs seem very remote (indeed, they will likely fall on someone else's shoulders)? How can it really motivate people to defer their own desires when their felt needs are so powerful? How do naturally selfish people inculcate the awareness that the forests and waters of this world are not ultimately ours, but belong to something bigger-whether future generations, or the global community, or God? National and local policy, land use regimes, and politicaleconomy obviously powerfully shape the conditions that make consumption or prudence an optimal strategy for individuals and groups. But the persistence of sacred groves over decades, perhaps centuries, suggests that a fundamental sense of humility also has a huge role to play in deciding our future.

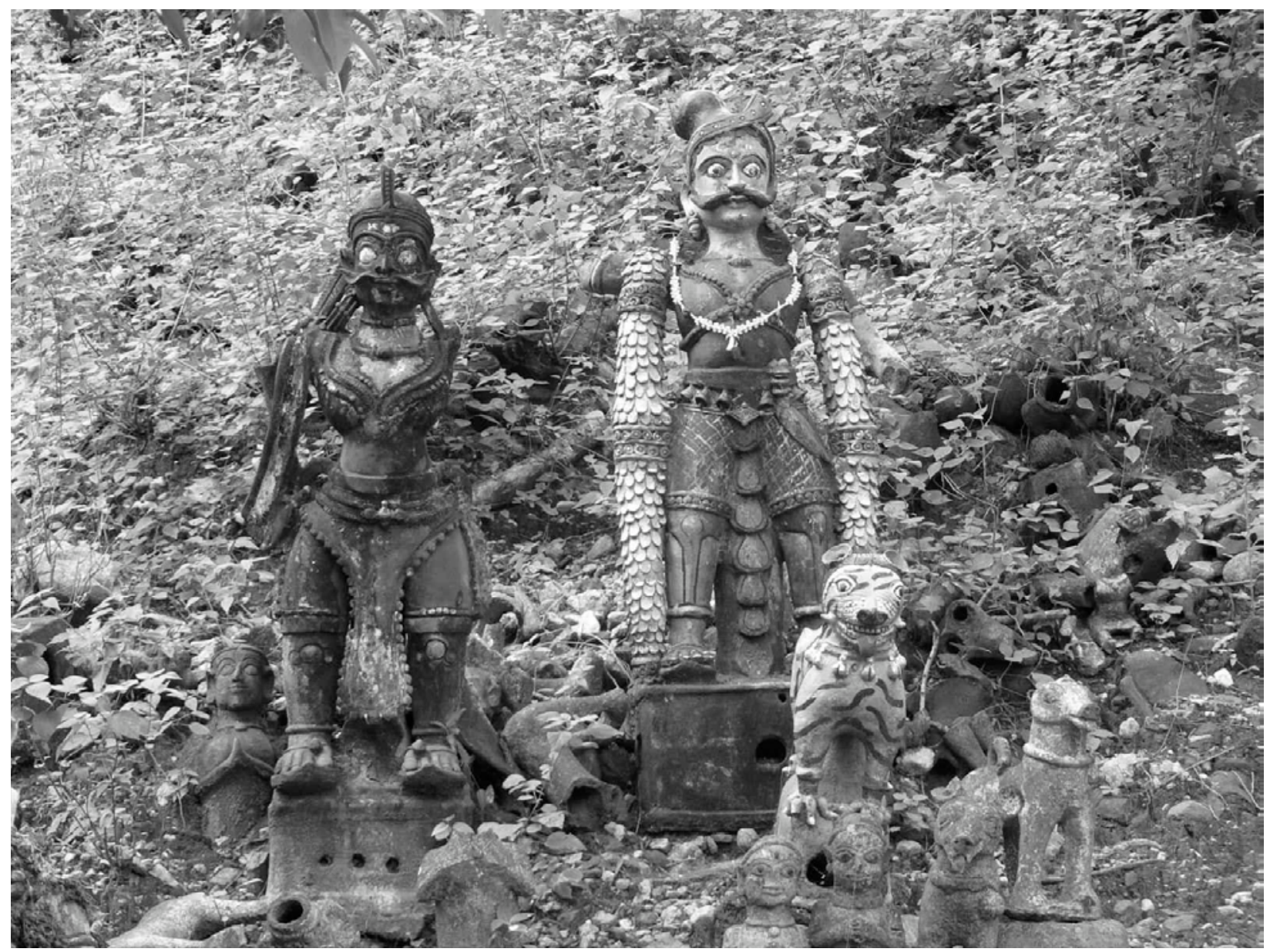

Figure 1. Votive offerings in the forest surrounding Sri Manjalmalaiyandi Shrine, Tamil Nadu, India 
108 Eliza Kent

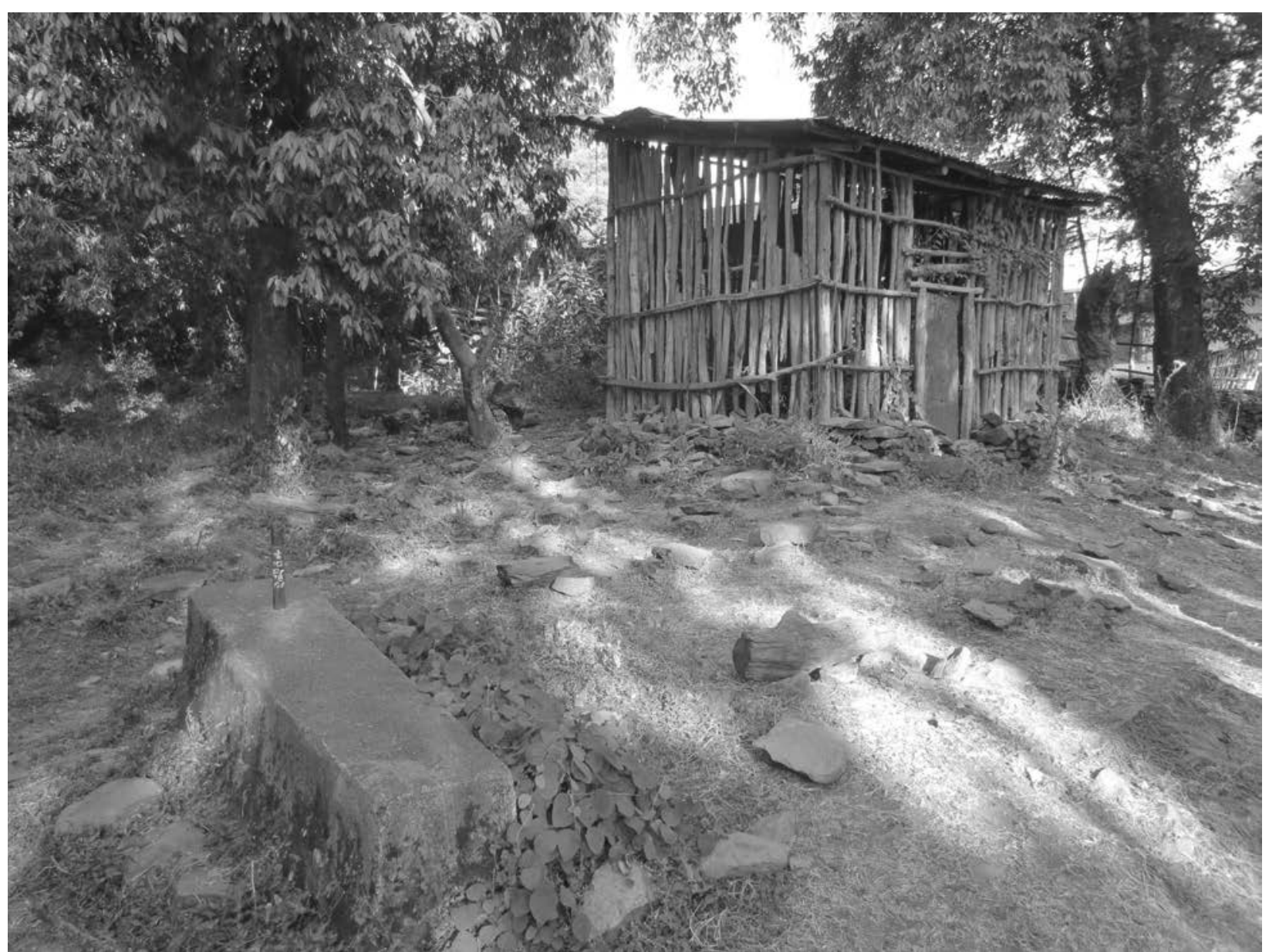

Figure 2. Grave stone and grave house in the forest surrounding St. Giyorgis Church, Amhara Region, Ethiopia 